\title{
Pharmacognostic and Phytochemical Evaluation of the bark of Grewia tiliifolia Vahl.
}

\author{
Jaya Kuruvilla', M. Anilkumar ${ }^{2, *}$
}

\section{Jaya Kuruvilla', M. Anilkumar ${ }^{2, *}$}

'Department of Botany, St. Xavier's College, Aluva-683102, Ernakulam, Kerala, INDIA. ${ }^{2}$ Department of Botany, Union Christian College, Aluva-683102, Ernakulam, Kerala, INDIA.

\section{Correspondence}

M. Anilkumar

Department of Botany, Union Christian

College, Aluva-683102, Ernakulam, Kerala, INDIA.

E-mail: drmakumar@gmail.com

History

- Submission Date: 16-05-2020;

- Review completed: 01-06-2020;

- Accepted Date: 22-06-2020

DOI : 10.5530/pj.2020.12.137

Article Available online

http://www.phcogj.com/v12/i5

Copyright

(C) 2020 Phcogj.Com. This is an openaccess article distributed under the terms of the Creative Commons Attribution 4.0 International license.

\section{ABSTRACT}

Introduction: Grewia tiliifolia Vahl. is an important ethnomedicinal tree widely distributed in the tropical and sub-tropical areas and has been used as a source of herbal shampoo by the local communities in many places of Kerala, India. It has been routinely used in the traditional Ayurvedic medicines against cough, ulcers, cancer, skin diseases, pruritus, wounds and urinary infections. Objective: The aim of this study was the pharmacognostical standardisation of $G$. tiliifolia. Methods: Pharmacognostic evaluation of G.tiliifolia bark was carried out by usual macroscopic and microscopic examinations and phytochemical screening. In addition, the quantification of major phytoconstituents such as alkaloids, flavonoids, phenols, tannins, saponins and carotenoids were carried out by standard procedures which can further throw light on the medicinal use of this ethnobotanically important plant. Results: Anatomical studies revealed the presence of prismatic crystals of calcium oxalate and druses in the stem and bark. Mucilage cavities were observed only in the stem. Histochemical studies revealed that the tissues of phloem parenchyma are the main localising region of various phytoconstituents. The physicochemical examinations along with the estimation of alkaloids, flavonoids, phenols, tannins, saponins and carotenoids will help in setting the pharmacopoeial standards of G.tiliifolia. Conclusion: The present study provides useful information that will help in the exact identification as well as assessment of purity of crude drugs of G.tiliifoia.

Key words: Grewia tiliifolia, Pharmacognostic studies, Physicochemical evaluation, Phytochemical screening, Quantification of phytoconstituents.

\section{INTRODUCTION}

The search for natural compounds of medical importance has increased recently due to their minimal or no side effects, easy availability and affordable prize. However, in many instances natural drugs pose chances of adulteration or substitution. Thus, pharmacognosy is of great significance in the exact identification of raw drug samples and also to distinguish them from adulterants or substitutes. In pharmacognostic investigations, standardization and authentication of natural drugs through phytochemical, physicochemical and morphological studies are usually conducted to ensure their identity. Such investigations are relevant to the pharmaceutical industries for quality control and in the field of pharmacological evaluation and development of formulations for various diseases. This will help in maintaining the quality of herbal products and their therapeutic efficacy. ${ }^{1}$

Grewia tiliifolia Vahl. is an ethnomedicinally important plant belonging to the family Tiliaceae. The plant has potential medicinal uses and $\beta$-sitosterol and stigmasterol were identified from the stem bark. ${ }^{2,3}$ The mucilage and hot water extract of G. tiliifolia bark can be used as an antidote for opium poisoning. ${ }^{4}$ $\gamma$-lactones of hepatoprotective properties have been isolated from the stem bark of G. tiliifolia through bioassay-directed fractionation and chromatography of methanol extract. ${ }^{5}$ Study on analgesic and anti- pyretic activities of G. tiliifolia leaves proved that the aqueous extract has an effect comparable to that of paracetamol. ${ }^{6}$ Lupeol isolated from G. tiliifolia can cause apoptosis in many cancer cells. ${ }^{7}$ The presence of lupeol and betulin were reported in three species of Grewia viz G. bicolor and G. tiliifolia. ${ }^{4,8}$ The bark of this plant is used as a source of herbal shampoo by the local populations in many areas of Kerala, India, after pressing and softening. Hence the present study has been undertaken that describes its pharmacognostic standardisation via macroscopic and microscopic characterization, physicochemical analysis and phytochemical studies with special emphasis on the stem bark.

\section{MATERIALS AND METHODS}

\section{Collection and authentication of plant} material

Fresh stem and bark of G. tiliifolia was collected from Muvattupuzha region of Ernakulam District, Kerala, India. The taxonomic identification was done at the Silviculture Department, Kerala Forest Research Institute (KFRI), Peechi and voucher specimen was deposited with accession No. 13053.

\section{Processing of plant material}

The present study focused on the stem and bark of G. tiliifolia owing to its use as a source of herbal shampoo. The stem and bark of G. tiliifolia was washed well in running tap water followed by rinsing in 
double distilled water. Fresh specimen as well as specimen fixed in FAA (Formalin - 10\%, 70\% Ethyl alcohol - 50\%, Acetic acid - 5\% + 35\% water) were used. For dry specimen preparation, they were chopped and shade dried to complete dryness. It was powdered using an electric blender and passed through a sieve of 60 mesh size to get fine powder.

\section{Pharmacognostic evaluation}

\section{Macroscopic evaluation}

Morphological parameters are important taxonomic tools for the identification of plant species. The morphological characterization of whole plant, particularly leaves, flowers and stem were noted.

\section{Microscopic evaluation}

Anatomical studies - Both free hand sections and microtome sections were taken to study the diagnostic anatomical characters of the bark.

Hand sectioning - Fresh materials were used for free hand sections and single staining was done with safranin and toludene blue $\mathrm{O}$ and photomicrographs were taken. ${ }^{9}$

Microtome sectioning - The bark specimens fixed in FAA were dehydrated by passing through a graded series of tertiary butyl alcohol (TBA). ${ }^{10}$ The sections were dewaxed with xylene, passed through ethyl alcohol series and then stained with safranin. ${ }^{11}$

\section{Scanning electron microscopic studies}

The cell inclusions were analysed using Scanning Electron Microscopy. A modified methodology proposed by Talbot and White was used for the preparation of specimens. ${ }^{12}$ The photomicrographs were taken using TESCAN VEGA 3 SBH scanning electron microscope.

\section{Histochemical localization studies}

Temporary mounts of fresh plant sections were used for histochemical localization studies. Free hand sections of stem/bark were taken and treated with respective reagents to localize the components. Histochemical localization was carried out with various reagents viz. Lugol's iodine for starch ${ }^{11}$ as well as for alkaloids, ${ }^{13}$ Biuret reaction for total proteins, ${ }^{14}$ Sudan III for lipids, ${ }^{15}$ Sudan red for fixed oil ${ }^{16}$ Schiff's reagent for lignin, ${ }^{17}$ Ruthenium red for mucilage, ${ }^{16}$ Wagner's reagent for alkaloids, ${ }^{18}$ Aqueous $\mathrm{NaOH}$ for flavonoids and Aqueous Ferric chloride for phenolic compounds ${ }^{11}$ and Hydrochloric vanillin for tannins. ${ }^{19}$

\section{Powder microscopy}

Powder microscopic studies were conducted based on the methodology of Khandelwal. ${ }^{20}$ The powdered sample was cleared with chloral hydrate solution. It was then treated with phloroglucinol and hydrochloric acid and mounted in glycerine.

\section{Physicochemical analysis}

Calibrated digital $\mathrm{p}^{\mathrm{H}}$ meter (Eutech instruments, $\mathrm{p}^{\mathrm{H}}$ 5-10) was used to measure the $\mathrm{p}^{\mathrm{H}}$ of $1 \%$ and $10 \%$ aqueous extracts. ${ }^{21}$ The determination of moisture content, ash values and extractive values were done based on the methodology of Ayurvedic Pharmacopoeia of India. ${ }^{22}$

\section{Preliminary phytochemical screening}

The preliminary phytochemical screening was done based on the standard protocol of Harborne to determine the presence of various phytoconstituents present in them..$^{23}$

\section{Preparation of extracts}

$10 \mathrm{~g}$ of the plant powder was mixed with $50 \mathrm{ml}$ of different solvents (Petroleum ether, chloroform, ethyl acetate, acetone, methanol and distilled water) and kept for 48 hours with intermittent shaking. The extract was filtered and kept in water bath for 2 hours at $60^{\circ} \mathrm{C}$ and was used for further analysis.

\section{Quantification of phytoconstituents}

\section{Total saponin content}

The total saponin content was determined based on the methodology of Obadoni and Ochuko. ${ }^{24} 20 \mathrm{~g}$ of grounded sample was taken in a conical flask and $100 \mathrm{ml}$ of $20 \%$ aqueous ethanol was added. It was heated on a hot water bath for 4 hours by stirring continuously at a temperature of $55^{\circ} \mathrm{c}$. This mixture was filtered and the residue was extracted with another $200 \mathrm{ml}$ of $20 \%$ ethanol. Both the extracts were mixed together and were reduced to $40 \mathrm{ml}$ by keeping in a hot water bath at $90^{\circ} \mathrm{c}$. It was then transferred into a $250 \mathrm{ml}$ separating funnel. $20 \mathrm{ml}$ of diethyl ether was added and shaken thoroughly. The aqueous layer obtained was taken and ether layer was discarded. This purification process was repeated many times. $60 \mathrm{ml}$ of $\mathrm{n}$-butanol was added and the combined extract of n-butanol was washed twice with $10 \mathrm{ml}$ of $5 \%$ aqueous sodium chloride. The remaining solution was heated in a water bath and after evaporation the samples were dried in an oven. The dried quantity was weighed and saponin content was calculated as percentage.

$\%$ of saponin = Weight of saponins x $100 /$ Weight of sample

\section{Total alkaloid content}

The total alkaloid content was estimated based on the methodology of Khadabadi et al. ${ }^{25} 5 \mathrm{~g}$ of powdered sample was mixed with $50 \mathrm{ml}$ of $10 \%$ sodium hydroxide and sonicated for 10 minutes. $50 \mathrm{ml}$ chloroform was added and sonicated for 10 minutes. This was filtered and $50 \mathrm{ml}$ chloroform was added and sonicated. This was filtered and then taken in a separating funnel. The lower chloroform layer was taken and upper layer was discarded. $50 \mathrm{ml}$ of distilled water was added to the chloroform layer, shaken and the lower layer was collected. This process was repeated one more time. To the collected layer, $50 \mathrm{ml}$ of $\mathrm{IN} \mathrm{HCl}$ was added and lower layer was collected. This was repeated again and to the collected layer, $30 \mathrm{ml}$ of $30 \%$ ammonia solution was added. The lower separated layer was collected in a pre-weighed beaker. It was kept in water bath and then in oven for drying. The weight of the residue obtained was noted. The percentage of total alkaloids was calculated using the formula

$\%$ of alkaloid $=\frac{\text { Weight of residue }}{\text { Weight of sample }} \times 100$

\section{Total flavonoid content}

The total flavonoid content was estimated using aluminium chloride colorimetric method proposed by Khadabadi et al. ${ }^{25} 0.5 \mathrm{~g}$ of sample powder was mixed with $25 \mathrm{ml}$ methanol and sonicated for about 15 minutes. It was filtered into $25 \mathrm{ml}$ standard flask and made up to 25 $\mathrm{ml}$ with methanol. $0.5 \mathrm{ml}$ of the sample was mixed with $0.1 \mathrm{ml}$ aluminium chloride $(10 \%), 0.1 \mathrm{ml}$ sodium acetate $(1 \mathrm{M}), 1.5 \mathrm{ml}$ ethanol and $2.8 \mathrm{ml}$ distilled water. Similarly, $0.5 \mathrm{ml}$ of standard quercetin ( $40 \mathrm{ppm}$ ) was also mixed with the above reagents. These mixtures were allowed to stand for 30 minutes and absorbance was measured at $415 \mathrm{~nm}$ using spectrophotometer (Varian 50 Bio with CaryWin UV software). The total flavonoid content was expressed as percentage and calculated using the formula

TFC $=\frac{\text { Absorbance of sample }}{\text { Absorbance of standard }} \times \frac{\text { Conc. of standard }}{\text { Conc. of sample }} \times \frac{\text { Purity of standard }}{100} \times 100$

\section{Total phenolic content}

The total phenolic content was determined by Folin-Ciocalteu method. ${ }^{25}$ $0.5 \mathrm{~g}$ of the powder sample was mixed with $10 \mathrm{ml}$ of $90 \%$ methanol and centrifuged at $2800 \mathrm{rpm}$ for 5 minutes. The supernatant was filtered into $25 \mathrm{ml}$ standard flask. The residue was again mixed with $10 \mathrm{ml}$ of $90 \%$ methanol and centrifuged at $2800 \mathrm{rpm}$. This was filtered into standard 
flask and was made up to $25 \mathrm{ml}$ with $90 \%$ methanol. $0.1 \mathrm{ml}$ of this sample solution was mixed with $5 \mathrm{ml}$ of $10 \%$ Folin-Ciocalteu reagent, $4 \mathrm{ml}$ of $7.5 \%$ sodium carbonate and $0.9 \mathrm{ml}$ of distilled water. This mixture was incubated for 1 hour in dark and absorbance was measured at $765 \mathrm{~nm}$ using spectrophotometer (Varian 50 Bio with CaryWin UV software). Various concentrations of gallic acid were used (standard) for preparing the calibration curve. The total phenolic content was calculated from the calibration curve and the results were expressed as gallic acid equivalents.

\section{Total tannin content}

Total tannin was determined by titrimetric method ${ }^{25} .1 \mathrm{~g}$ of powdered sample was mixed with $75 \mathrm{ml}$ distilled water and sonicated for 10 minutes. It was filtered and mixed with $25 \mathrm{ml}$ of indigosulfonic acid. This mixture was titrated with $0.1 \mathrm{~N}$ potassium permanganate solution until the formation of golden yellow colour (end point) and the burette reading $(\mathrm{Xml})$ was noted. Titration of blank (water) was also performed using the same procedure and blank reading (Yml) was noted. The percentage of tannin content was calculated using the following formula with reference to dry weight of substance taken.

$\%$ of tannin $=\frac{(\mathrm{X}-\mathrm{Y}) \mathrm{ml} \times 0.004157 \times \text { Normality of } \mathrm{KMnO} 4 \times 100}{\text { Weight of sample taken } \times 0.1 \mathrm{~N}}$

\section{Total carotenoid content}

The carotenoid content of G. tiliifolia Vahl. bark was estimated based on the methodology of Harborne. ${ }^{26} 100 \mathrm{mg}$ of fresh bark was taken along with $10 \mathrm{ml}$ of $80 \%$ acetone. It was ground well and centrifuged at 3000 rpm for 10 minutes. The supernatant was taken and made up to $10 \mathrm{ml}$. The absorbance was measured at $480 \mathrm{~nm}$ using UV spectrophotometer. The total carotenoid content was expressed in $\mathrm{mg} / \mathrm{g}$ and was calculated using the following formula
Amount of carotenoids in $100 \mathrm{mg}$ plant tissue $=\frac{4 \times \text { OD value } \mathrm{x} \text { Total volume of sample }}{\text { Weight of fresh plant tissue }}$

\section{RESULTS}

\section{Macroscopic evaluation}

G. tiliifolia is a 'medium to large sized tree attaining a height of about $12-15 \mathrm{~m}$ (Figure 1A). The bark is dark brown, rough, fibrous with red colouration inside (Figure 1B). Leaves are simple, alternately arranged and reddish when young (Figure 1C). The lamina is $13-16.5 \times 8-11.5 \mathrm{~cm}$, large, broadly ovate, base obliquely cordate, margins serrate, glabrous above and pubescent beneath. Petiole is short and pubescent with a swollen tip. Stipules are leafy, veined and pubescent with a rounded lobe on the lower side (Figure 1D).

Flowers are small, yellow, bisexual and borne in axillary umbels (Figure 1E). Sepals 5 and pubescent outside. Petals 5 , yellow coloured, become red at a later stage and half the length of sepals. Stamens are many, free with yellow filaments that turn red (Figure1F). They are inserted on a glandular torus. Ovary is superior with style longer than the stamens ending in a lobed stigma. Fruit is a drupe, globose or 2 lobed with 1 or 2 seeds, turning red when ripe (Figure $1 G$ ) and seeds are creamy white (Figure 1H).

\section{Microscopic evaluation}

\section{Anatomy of stem}

The outer epidermis consisted of single layer of columnar cells covered by thick cuticle. It contained numerous stellate trichomes which were 5-7 armed. The hypodermis comprised of 3-5 layers of collenchyma in which few cells contained prismatic crystals (Figures 2A \& 2B). The cortex was made of 5-6 layered thin walled parenchyma cells with mucilage cavities (Figure 2C). The parenchyma cells close to the pericycle also

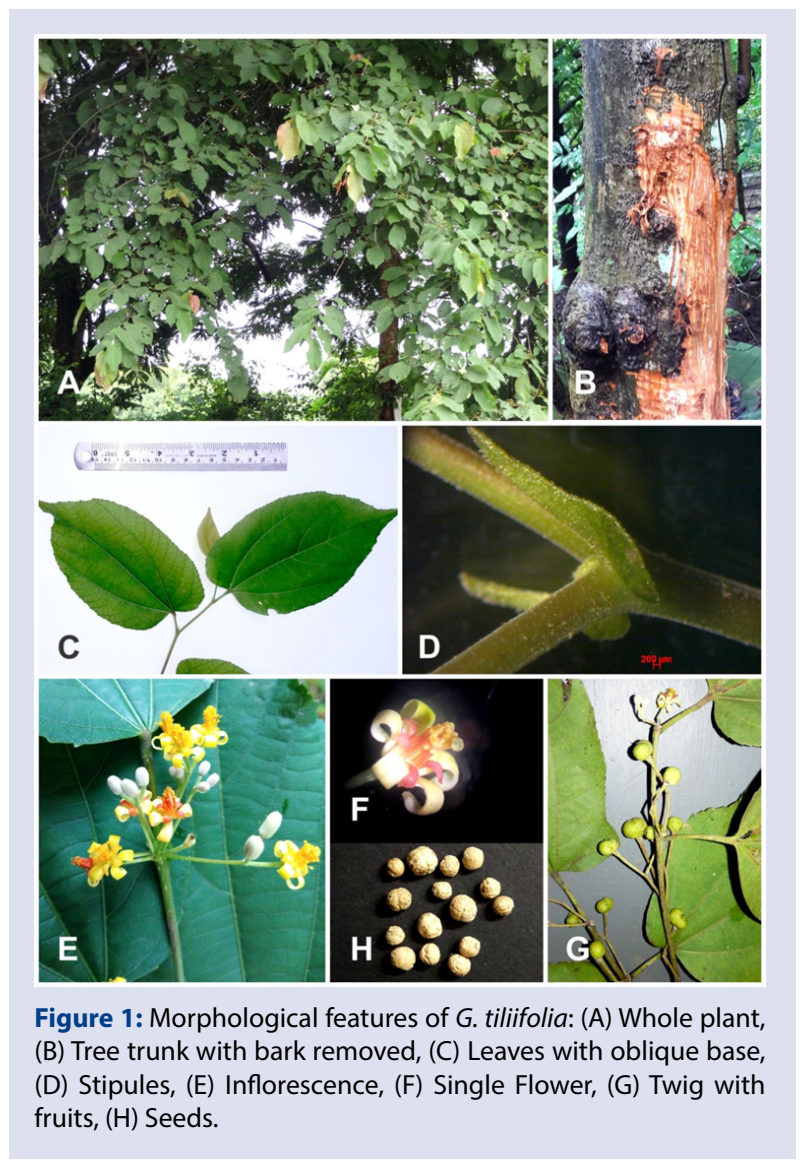


contained prismatic crystals. Pericycle was 6-8 layered and made of thick walled cells (Figure 2D). This was followed by phloem which contained numerous calcium oxalate crystals. Next to phloem was cambium followed by xylem. There was a large central pith made of thin walled parenchyma cells in which starch grains were very prominent (Figure $2 \mathrm{E} \& 2 \mathrm{~F}$ ). Mucilage cavities were also present in the pith region having an inner lining of secretory cells. Protein was histochemically localized in the cells of pith and cortex (Figure 2H). Lignin was localized in the pericycle region (Figure $2 \mathrm{G}$ ) and mucilage was observed in the region of epidermis and vascular tissues (Figure 2I).

During secondary growth, periderm was formed in the outer most region. This includes the outer phellum (cork), middle phellogen (cork cambium) and inner phelloderm. Small raised openings called lenticels were formed in the bark for diffusion of gases (Figure $3 F \& 3 G$ ). Cork consisted of few layers of thick walled cells and cork cambium was made up of thin walled parenchymatous cells. Below the phelloderm was few layers of cortex. This was followed by secondary phloem which comprised of wide phloem rays and phloem fibers. Calcium oxalate crystals were found in the phloem rays and prismatic crystals were observed lying close to the phloem fibers (Figure 3B). The vascular cambial strip was present in between secondary phloem and secondary xylem. Large amounts of secondary xylem were produced towards the inner side and distinct growth ring formation was observed (Figure 3A). Secondary xylem was made up of large xylem vessels, tracheids and multiseriate xylem rays (Figure 3C). Primary xylem was seen near the parenchymatous pith. Mucilage cavities were embedded in the pith (Figure 3D).

\section{Histochemical localization studies}

\section{Starch}

Presence of starch was detected by treating the sections with Lugol's iodine. Bark gave a negative reaction for starch. But it gave a positive reaction for alkaloids by the formation of brown colouration in the phloem parenchyma (Figure 4A).

\section{Protein}

The presence of proteins was characterized by red colouration formed due to biuret reaction. In the bark, proteins were located in phellogen and phloem parenchyma (Figure 4B).

\section{Lipids}

Lipids were detected by the formation of reddish globules when treated with Sudan III. The lipid globules were present in the cells of phloem parenchyma (Figures 4C \& 4D).

\section{Fixed oil}

Fixed oil was localized by treating bark with Sudan red solution. Oil droplets appeared as orange pink coloured globules in the phloem parenchyma cells (Figures 4E \& 4F).

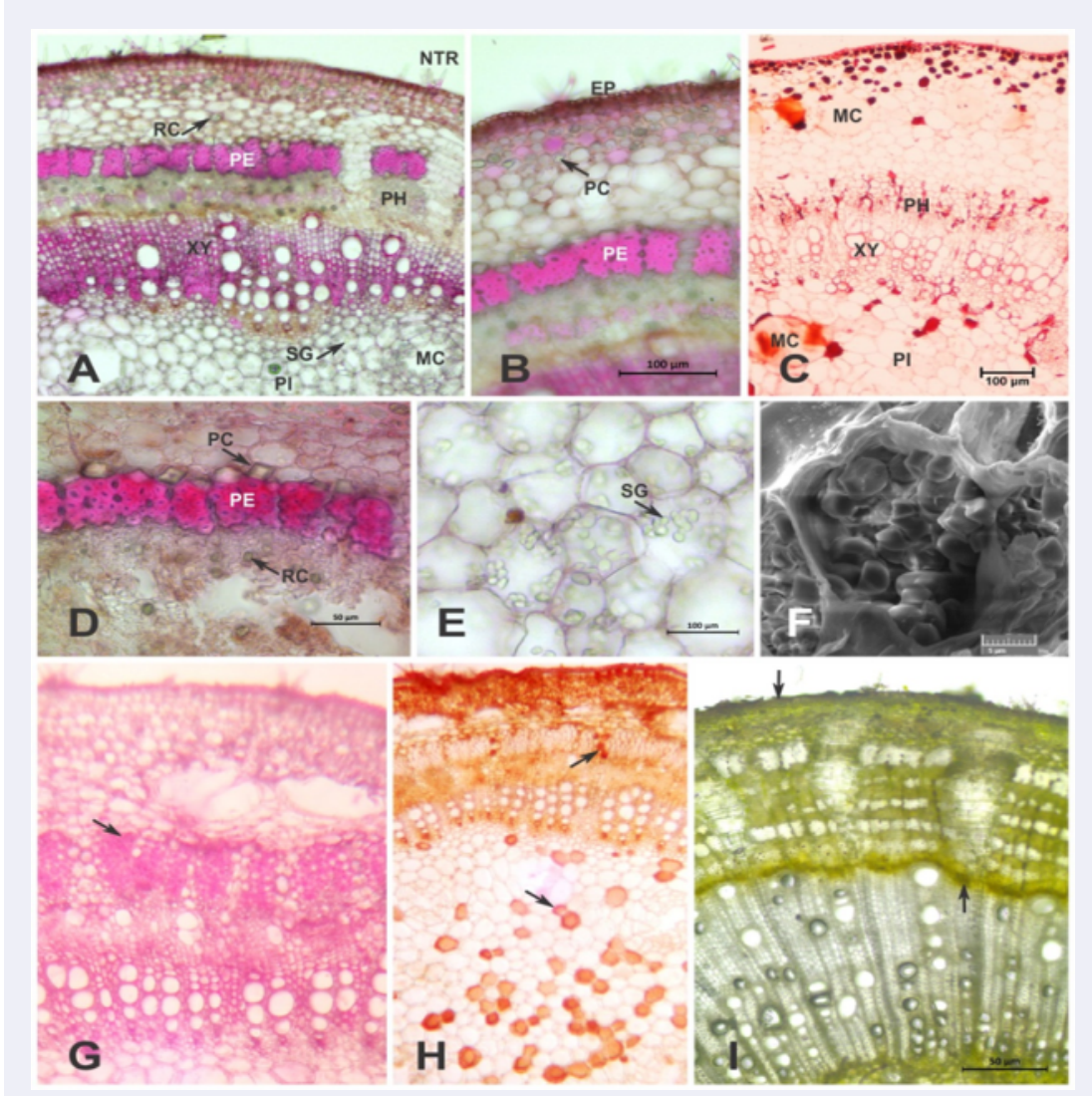

Figure 2: Anatomy and histochemistry of young stem (A) T.S of young stem stained in safranin (B) Portion of stem magnified (C) Microtome section of young stem (D) Enlarged view of stem showing rosette and prismatic crystals (E) Starch grains under light microscope (F) Starch grains under scanning electron microscope (G) Lignin stained magenta with Schiff's reagent $(\mathrm{H})$ Protein stained by biuret reaction (I) Mucilage stained yellow with ruthenium red. NTR-Non glandular trichome, RC-Rosette crystal, PE-Pericycle, XY-Xylem, PHPhloem, SG-Starch grains, MC-Mucilage cavity, PC-Prismatic crystal, EP-Epidermis, PI-Pith. 


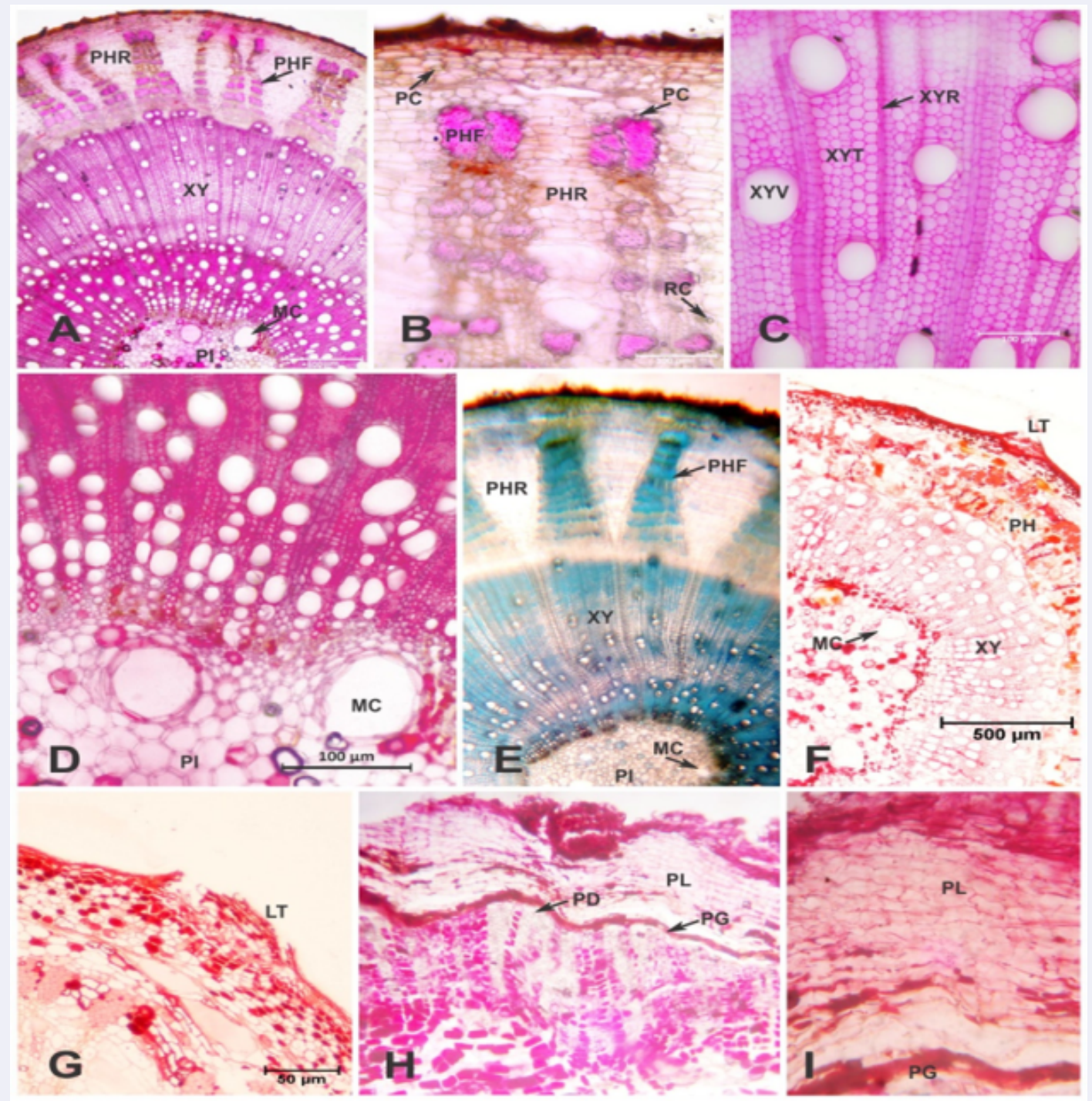

Figure 3 : Anatomy of mature stem and bark: (A) T.S of mature stem stained in safranin, (B,C\&D) Portion of the stem magnified, (E) T.S of mature stem stained in toludene blue, $(F \& G)$ Microtome sections of mature stem with lenticel, $(H)$ Microtome section of bark, (I) Enlarged view of periderm region. PHR-Phloem rays, PHF-Phloem fibre, XY-Xylem, MCMucilage cavity, PI-Pith, PC-Prismatic crystal, RC-Rosette crystal, XYV-Xylem vessel, XYT-Xylem tracheid, XYR-Xylem ray, LT-Lenticel, PH-Phloem, PL-Phellum, PD-Phelloderm, PG-Phellogen.

\section{Lignin}

Lignin can be localized histochemically by treating sections with Schiff's reagent. The presence of lignin was observed abundantly in the thick walled cells of bark (Figure 5F).

\section{Mucilage}

When treated with ruthenium red, the bark of G. tiliifolia stem showed the presence of pinkish red mucilage, whereas yellow mucilage was observed in the cortex, phloem and pith (Figures 5A \& 5B).

\section{Alkaloids}

The reaction of fresh sections with Wagner's reagent revealed the presence of alkaloids in the bark. This was characterized by reddish brown colouration in the phloem parenchyma (Figure 5C).

\section{Flavonoids}

The presence of flavonoids in the bark was verified by the formation of vine red colouration, when treated with aqueous $\mathrm{NaOH}$. Flavonoids were distributed in the regions of phellogen and phloem parenchyma (Figure 5D).

\section{Phenolic compounds}

Treatment of sections with aqueous ferric chloride revealed the presence of black coloured phenolic contents in the phloem parenchyma of the bark (Figure 5G)

\section{Tannins}

The presence of tannins was verified by red colouration when treated with vanillin- $\mathrm{HCl}$ in the cells of phloem parenchyma of the bark (Figure 5E).

\section{Powder microscopy}

The powder of G. tiliifolia bark was light brown in colour with a distinguishing odour. It was characterized by fragments of lignified parenchyma cells, starch grains, rosette crystal of calcium oxalate, parenchyma cells with starch grains, oil globules, fragments of cork cells, fragments of lignified parenchyma cells, pericyclic fibre with 


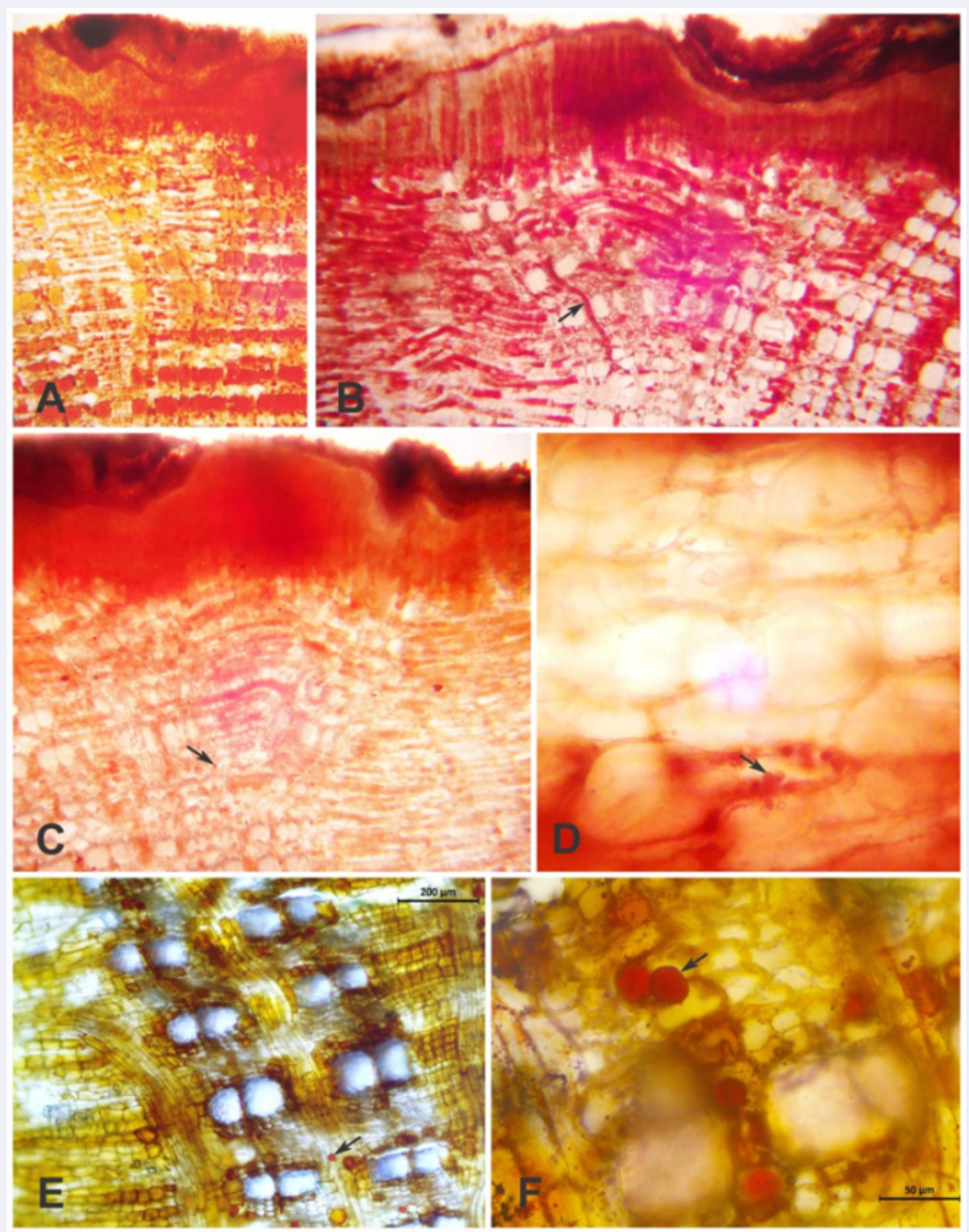

Figure 4: Histochemical localization in the bark tissues (A)Absence of starch when treated with Lugol's iodine (B) Protein stained red by biuret reaction (C\&D) Lipid globules stained red with Sudan III (E\&F) Fixed oil stained orange pink with Sudan red.

moderately wide lumen and tapered apices, prismatic crystals and fragments of lignified xylem vessel with scalariform thickening.

\section{Physicochemical analysis}

The $\mathrm{p}^{\mathrm{H}}$ value was found in the acidic range. For $1 \%$ solution it was $5.40 \pm 0.01$ and for $10 \%$ solution, $\mathrm{p}^{\mathrm{H}}$ value was $5.62 \pm 0.01$. Moisture content was recorded as $13.29 \pm 0.01 \%$. Among the five solvents used for extraction, water was found to be the best extraction solvent because it separated out higher amount of phytoconstituents from the plant powder $(10.03 \pm 0.04 \%)$. The next higher value was given by alcohol $(9.31 \pm 0.07 \%)$. The lowest extractive value was shown by ethyl acetate $(1.31 \pm 0.06 \%)$. This indicated that comparatively lesser number of phytoconstituents were leached out in ethyl acetate. G. tiliifolia bark powder exhibited a total ash value of $12.69 \pm 0.02 \%$. The acid insoluble ash value was $2.44 \pm 0.03 \%$ whereas water soluble ash value was $3.50 \pm 0.02 \%$ (Table 1 ).

\section{Phytochemical studies}

Preliminary phytochemical screening of the different extracts revealed the presence of flavonoids, tannins, alkaloids, terpenoids, saponins, phenols and carbohydrates whereas coumarins, quinines, anthraquinones, resins, reducing sugars and proteins were absent. In the water extract all such compounds gave negative results (Table 2). 


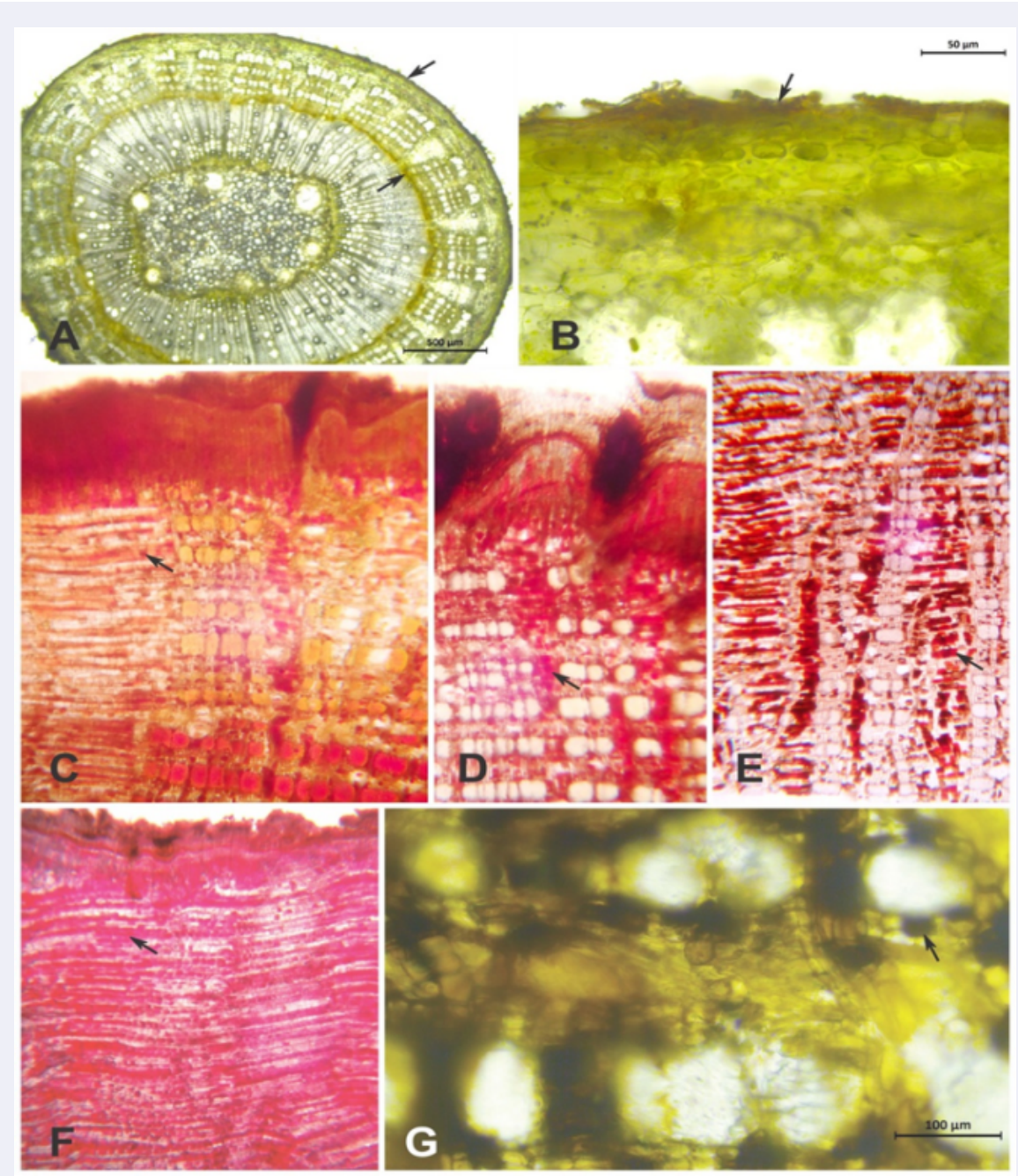

Figure 5: Histochemical localization in the bark tissues (A \& B) Mucilage stained yellow and pinkish red with Ruthenium red (C) Alkaloids stained reddish brown with Wagner's reagent (D) Flavonoids stained wine red with aqueous $\mathrm{NaOH}$ (E) Tannins stained red with hydrochloric vanillin (F) Lignin stained magenta with Schiff's reagent (G) Phenols stained black with aqueous ferric chloride.

Table 1: Physicochemical analysis.

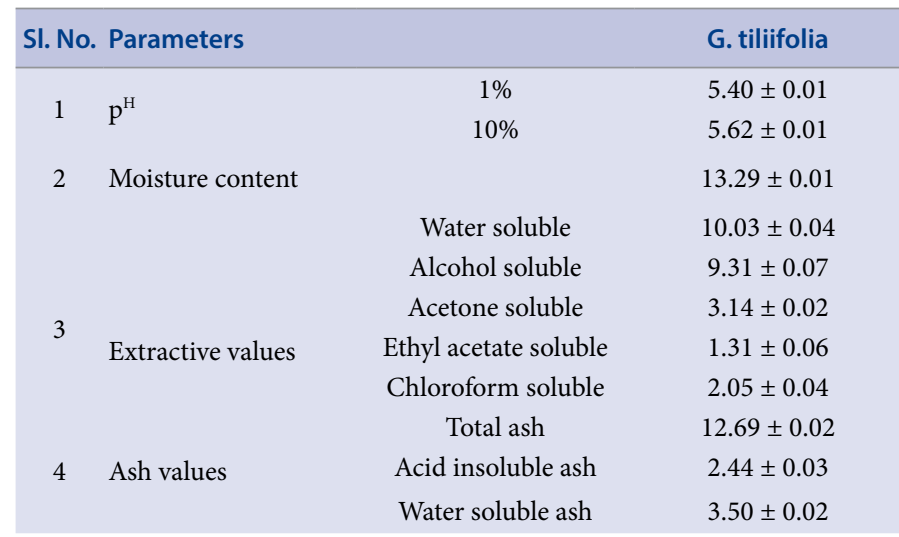

The estimation revealed the presence of very low quantities of flavonoids and carotenoids when compared to alkaloids, phenols, tannins and saponins and the results are summarized in Table 3.

\section{DISCUSSION}

The morphological characterization of plants provides valuable information about their botanical identity and thus helps in differentiating the drug from its substituents. The oblique and heart shaped leaf base and characteristic flower helps to identify G. tiliifolia.

The presence of calcium oxalate crystals, their chemical composition, morphology and location within the plant can be a useful tool in the characterization of taxonomic groups and also in the identification and purity of plant drugs. ${ }^{28-30}$ In G. tiliifolia prismatic crystals of calcium oxalate were present in addition to druses. In the creeping plant Ipomoea asarifolia the presence of crystals is a defense mechanism against attack by ruminant animals. ${ }^{31}$ These crystals help to give protection from herbivores, to maintain ionic balance through storage of calcium and oxalate in idioblasts and support the plants. ${ }^{32}$ Histochemical and morphoanatomical studies in the leaves of Luehea divaricata Mart. (Malvaceae) reported the presence of prismatic calcium oxalate crystals, druses and mucilage. ${ }^{33}$ 
Table 2: Preliminary phytochemical screening.

\begin{tabular}{|c|c|c|c|c|c|c|c|}
\hline SI.No. & Phytoconstituents & Petroleum Ether & Chloroform & Ethyl Acetate & Acetone & Methanol & Distilled water \\
\hline 1 & Flavonoids & + & - & + & - & + & - \\
\hline 2 & Coumarins & - & - & - & - & - & - \\
\hline 3 & Tannins & - & + & - & + & + & - \\
\hline 4 & Alkaloids(Mayer’s) & + & - & + & - & + & - \\
\hline 5 & Alkaloids(Wagner's) & - & - & - & - & - & - \\
\hline 6 & $\begin{array}{c}\text { Steroids/ } \\
\text { Terpenoids }\end{array}$ & + & - & - & - & - & - \\
\hline 7 & Saponins & - & + & - & - & - & + \\
\hline 8 & Quinines & - & - & - & - & - & - \\
\hline 9 & Anthraquinones & - & - & - & - & - & - \\
\hline 10 & Phenol & - & + & + & + & + & - \\
\hline 11 & Resin & - & - & - & - & - & - \\
\hline 12 & $\begin{array}{l}\text { Reducing sugar/ } \\
\text { Glycoside }\end{array}$ & - & - & - & - & - & - \\
\hline 13 & Protein & - & - & + & - & - & - \\
\hline 14 & Carbohydrate & + & + & + & + & + & + \\
\hline
\end{tabular}

Table 3: Estimation of phytoconstituents.

\begin{tabular}{ccc}
\hline SI.No. & Phytoconstituent & Quantity (\%) \\
\hline 1 & Total alkaloid & $0.92 \pm 0.04$ \\
2 & Total flavonoid & $0.14 \pm 0.03$ \\
3 & Total phenol & $3.90 \pm 0.03$ \\
4 & Total tannin & $8.60 \pm 0.05$ \\
5 & Total saponin & $3.40 \pm 0.03$ \\
6 & Total carotenoid & $0.15 \pm 0.01$ \\
\hline
\end{tabular}

In G. tiliifolia mucilage cavities were found embedded in the pith and cortical regions of the stem and were lined by small thin walled elongated cells. They undergo disintegration at the time of mucilage secretion. The presence of mucilage was also detected in the bark region. The occurrence of mucilage cavities in leaf was reported recently. ${ }^{34}$ According to Bakker and Gerritsen the mucilage cells of Hibiscus schizopetalus do not possess suberized wall layer. ${ }^{35}$ Here mucilage is deposited directly against the primary wall which later disintegrated to form mucilage cavities.

The combination of histochemistry and microscopy can provide substantial information about the cell wall composition, modifications, developmental stages and tissue differentiation. Histochemical localization studies allows a quick and cost effective method for the preliminary evaluation of plant species in search of new pharmaceuticals..$^{36-39}$ The tissues of phloem parenchyma was found to be the main localising region of various phytoconstituents in G. tiliifolia bark.

Powder microscopy is a cost effective, quick and reliable tool for detecting the adulterants and also to confirm the purity of crude drug. The analysis of G. tiliifolia bark powder revealed the presence of fragments of lignified parenchyma cells, starch grains, rosette crystal of calcium oxalate, prismatic crystals, parenchyma cells with starch grains, oil globules, cork cells, pericyclic fibres and xylem vessel with scalariform thickening. Oboh and Onwukaeme reported that the chemomicroscopical test conducted on the powder of Sida acuta leaves showed the presence of starch, calcium oxalate, mucilage and lignin. ${ }^{40}$ Powder microscopy of Pentace burmanica (Tiliaceae) contained fragments of fibers, starch grains, calcium oxalate prismatic crystals, fragments of parenchyma, resin and tannin masses in the bark powder. ${ }^{41}$

The evaluation of physicochemical parameters helps in the setting of pharmacopoeial standards. Ash value is one of the common parameters which are used to determine the identity and purity of a drug. ${ }^{42}$ The values of total ash, acid insoluble ash and water soluble ash were $12.69 \pm 0.02 \%$, $2.44 \pm 0.03 \%$ and $3.50 \pm 0.02 \%$ respectively in G. tiliifolia bark. The value of extractable matter varies according to the purity of crude drug and the polarity of solvent used. The determination of extractive values will help to assess the nature of chemical composition of a crude drug and to estimate the specific constituents soluble in a particular solvent. ${ }^{43}$ Water was the best extractive solvent for G. tiliifolia bark and the lowest extractive value was shown by ethyl acetate. Similar results were reported in Bombax ceiba bark also. ${ }^{21}$ The moisture content is related to the stability and quality of crude drugs because if the water content is high the drug will get deteriorated thereby spoiling the biomass and active principles present in it. ${ }^{44} G$. tiliifolia bark powder has $13.29 \pm 0.01 \%$ moisture content.

Phytochemical screening can help in detecting the bioactive compounds present in medicinal plants and thus lead to the discovery and development of drugs. ${ }^{45}$ The presence of flavonoids, tannins, alkaloids, steroids/ terpenoids, saponins and phenol were confirmed by the preliminary phytochemical screening of G. tiliifolia bark. Phytoconstituents which gave negative results were coumarins, quinines, anthraquinones, resin and reducing sugar/glycosides. The presence of alkaloids, flavonoids, terpenoids, tannins and saponins in the stem bark of G. optiva reported. ${ }^{46}$

In G. tiliifolia bark tannin showed the highest content $(8.60 \pm 0.05 \%)$ and flavonoid showed the lowest content $(0.14 \pm 0.03 \%)$. The aqueous fraction of the stem bark of G. optiva was reported to contain the highest content of phenol and flavonoid. ${ }^{46}$ Ejikeme et al. reported $4.8 \%$ of alkaloids and $4.4 \%$ of saponins in the wood of Glyphea brevis (Tiliaceae). ${ }^{47}$ The red colour exhibited by G. tiliifolia bark extract can be attributed to the presence of carotenoid pigments. The total carotenoid content was $0.15 \pm 0.01 \%$ which was comparable with that of many known plants. Carotenoids help in providing protection against cancer, macular degeneration and cardiovascular diseases ${ }^{48}$

The pharmacognostical evaluation can thus give valuable information regarding its morphology, microscopic features and physicochemical characteristics which will help in the exact identification as well as assessment of purity of crude drugs. 


\section{CONCLUSION}

The results obtained from this study can be used as a pharmacognostic standard for the exact identification and evaluation of the raw bark of G. tiliifolia.

\section{ACKNOWLEDGEMENT}

First author gratefully acknowledges the University Grants Commission (UGC, New Delhi) for sanctioning study leave under Faculty Development Programme (FDP).

\section{CONFLICTS OF INTEREST}

The authors declare that they have no conflicts of interest.

\section{REFERENCES}

1. Chanda S. Importance of pharmacognostic study of medicinal plants: An overview. J Pharmacog Phytochem. 2014;2(5):69-73.

2. Kuruvilla J. Pharmacognostic and anti-microbial investigations of selected plants for the formulation of herbal shampoo. Ph.D Thesis. Kottayam, Kerala, India: Mahatma Gandhi University; 2019.

3. Ahamed MBK, Krishna V, Gowdru HB, Rajanaika H, Kumaraswamy HM, Rajashekarappa $\mathrm{S}$, et al. Isolation of bactericidal constituents from the stem bark extract of Grewia tiliifolia Vahl. Res J Med Plant. 2007;1(3):72-82.

4. Badami S, Gupta MK, Ramaswamy S, Rai SR, Nanjaian M, Bendell DJ, et al. Determination of betulin in Grewia tiliifolia by HPTLC. J Separation Sci. 2004;27(1-2):129-31.

5. Ahamed MBK, Krishna V, Dandin CJ. In vitro antioxidant and invivo prophylactic effects of two $\gamma$-lactones isolated from Grewia tiliifolia against hepatotoxicity in carbon tetrachloride intoxicated rats. Eur J Pharmacol. 2010;31:42-52.

6. Sakat SS, Juvekar AR. Analgesic and antipyretic activity of aqueous extract of G. tiliifolia Vahl. leaves. J Pharm Res. 2009;2(9):1475-8.

7. Aratanechemuge $Y$, Hibasami $H$, Sanpin K, Katsuzaki H, Imai K, Komiya T. Induction of apoptosis by lupeol isolated from mokumen (Gossampinus malabarica L. Merr) in human promyelotic leukemia HL-60 cells. Oncol Rep. 2004;11:289.

8. Jaspers MWJM, Bashir AK, Zwaving JH, Malingre TM. Investigation of Grewia bicolour Juss. J. Ethnopharm. 1986;17(3):205-11.

9. O'Brien TP, Feder N, Mc Cully ME. Polychromatic staining of plant cell walls by toluidine blue O. Protoplasma. 1964;59(2):368-73.

10. Sass, JE. Elements of Botanical Microtechnique. New York: Mc Graw- Hill Book Co. Inc; 1940.

11. Johansen DA. Plant Microtechnique, 1st ed. New York:Mc Graw-Hill Book Co. Inc; 1940.

12. Talbot MJ, White RG. Methanol fixation of plant tissue for Scanning Electron Microscopy improves preservation of tissue morphology and dimensions. Plant Methods. 2013;9:36.

13. Yoder LR, Mahlberg PG. Reactions of alkaloid and histochemical indicators in laticifers and specialized parenchyma cells of Catharanthus roseus (Apocynaceae). Am J Bot. 1976;63:1167-73.

14. Gahan PB. Plant histochemistry and Cytochemistry - An introduction. Florida: Academic Press; 1984

15. Gomori G. Microscopic Histochemistry: Principles and Practice. Chicago: University press; 1952.

16. Quality Standards of Indian Medicinal Plants. Vol.15. New Delhi: Medicinal Plants Division, Indian Council of Medical Research; 2017.

17. Mc Lean RC, Cook WRI. Plant Science Formulae. London: Mac Millan; 1941.

18. Furr M, Mahlberg PG. Histochemical analyses of laticifers and glandular trichomes in Cannabis sativa. J Natural Products. 1981;44(2):153-9.

19. Valette C, Andary C, Geiger JP, Sarah JP, Nicole M. Histochemical and cytochemical investigations of phenols in roots of banana infected by the burrowing nematode Radopholus similis. Phytopathol. 1998;88:1141-8.

20. Khandelwal KR. Practical Pharmacognosy. 19th ed. Pune, India: Nirali Prakashan; 2008.

21. Wahab S, Hussain A, Ahmad P, Usmani S. Ethnobotanical, pharmacognostical and physicochemical studies of stem bark of Bombax ceiba L., commonly growing in Eastern Uttar Pradesh region of India. Pharmacog J. 2012;4(32):5560.
22. Ayurvedic Pharmacopoeia of India, Part - I, Volume -1, 1st edition. Ministry of Health and Family Welfare, Department of Health, Government of India, New Delhi. 1989.

23. Harborne JB. Phytochemical methods-A guide to modern techniques of plant analysis. London: Chapman and Hall; 1984.

24. Obadoni BO, Ochuko PO. Phytochemical studies and comparative efficacy of the crude extract of some homeostatic plants in Edo and Delta states of Nigeria. Global J Pure \& Appl Sci. 8:203-208.

25. Khadabadi SS, Deore SL, Baviskar BA. Experimental Pharmacognosy-A Comprehensive Guide. Pune: Nirali Prakashan; 2013.

26. Harborne JB. Phytochemical Methods. London: Chapman and Hall; 1973.

27. Metcalfe CR, Chalk L. Anatomy of Dicotyledonous. 2nd ed. Oxford: Clarendon Press; 1979.

28. Monje PV, Baran EJ. Characterization of calcium oxalates generated as biominerals in cacti. Plant Physiol. 2002;128:707-13.

29. Anjaneyulu B, Rao VB, Ganguly AK, Govindachari TR, Joshi BS, Kamat VN Chemical investigation of some plants. Ind J Chem. 1965;3:237.

30. Anitha R, Sandhiya T. Occurrence of calcium oxalate crystals in the leaves of medicinal plants. Int J Pharmacog. 2014;1:389-93.

31. Martins FM, Lima JF, Mascarenhas AAS, Macedo TP. Secretory structures of Ipomoea asarifolia: anatomy and histochemistry. Braz. J Pharmacog. 2012;22(1):13-20.

32. Larrosa CRR Duarte MR. Contribuicão estudo anatõmico do caule de Himatanthus sucuuba (Spruce ex Müll. Arg.) Woodson, Apocynaceae. Rev Bras Farmacogn. 2005;15:110-4.

33. Walker CIB, Zanetti GD, Ceron CS. Morfoanatomia e Histoquimica das folhas de Luehea divaricata Mart. Latin. Am J Pharmacy. 2008;27:203-210.

34. Kuruvilla J, Anilkumar M. Pharmacognostical studies in the leaves of Ceiba pentandra (L.) Gaertn. J. Pharmacog Phytochem. 2018;7(6):46-54.

35. Bakker ME, Gerritsen AF. The development of mucilage cells in Hibiscus schizopetalus. Acta Bot Neth. 1992;41:31-42.

36. Coelho VPM, Leite JPV, Nunes IG, Ventrella MC. Anatomy, histochemistry and phytochemical profile of leaf and stem bark of Bathysa cuspidate (Rubiaceae). Aust J Bot. 2012;260:49-60

37. Demarco D, Castro M M, Ascensao4 I. Two laticifier systems in Sapium haematospermum- new records for Euphorbiaceae. Botany. 2013;91:545-54.

38. Araújo N D, Coelho V P M, Ventrella M C, Agra M F. Leaf anatomy and histochemistry of three species of Ficus sect. Americanae supported by light and electron microscopy. Microsc Microanal. 2014;20:296-304.

39. Mercadante-Simões MO, Mazzottini-Dos-Santos HC, Nery LA, Ferreira PRB, Ribeiro LM, Royo VA, et al. Structure, Histochemistry and phytochemical profile of the bark of the sobol and aerial stem of Tontelea micrantha (CelastraceaeHippocrateoideae). A nais da Academia Brasileira de Ciencias. 2014;86(3):116779.

40. Oboh IE, Onwukaeme DN. Pharmacognostic evaluation of the leaves of Sida acuta Burm. F. (Malvaceae). J Phytomed Ther. 2007;12:56-65.

41. Duangyod T, Palanuvej $C$, Ruangrungsi N. Pharmacognostic specifications and quantification of $(+)$ - catechin and $(-)$ - epicatechin in Pentace burmanica stem bark. Pharmacog Res. 2014;6(3):251-6.

42. Nayak BS, Patel KN. Pharmacognostic study of Jatropha curcas leaves. Int J Pharm Tech Res. 2010;2:140-3.

43. Kumar S, Kumar V, Prakash O. Pharmacognostic study and anti-inflammatory activity of Callistemon lanceolatus leaf. Asian Pac J Trop Biomed. 2011;1(3):17781.

44. Gokhale SB, Kokate CK, Purohit AP. A text book of Pharmacognosy. Pune: Nirali Prakashan; 1995

45. Yadav M, Chatterji S, Gupta SK and Watal G. Preliminary Phytochemical Screening of Six medicinal Plants used in traditional medicine. Int Pharmaceutic Sci. 2014;6(5):539-42.

46. Anwar J, Shah HU, Ali R, Iqbal Z, Khan SM, Rahman IU, et al. Antioxidant activity and phytochemical screening of stem bark extracts of Grewia optiva Drummond ex Burret. J Pharmacogn and Phytochem. 2015;3(6):179-82.

47. Ejikeme CM, Ezeonu CS, Eboatu AN. Determination of physical and phytochemical constituents of some tropical timbers indigenous to Niger Delta area of Nigeria. European Sci J. 2014;10(18):247-70.

48. Reboul E, Richelle M, Perrot E, Desmoulins-Malezet C, Pirisi V, Borel P. Bioaccessibility of carotenoids and vitamin $E$ form their main dietary sources. J Agric Food Chem. 2006;54(23):8749-55. 


\section{GRAPHICAL ABSTRACT}

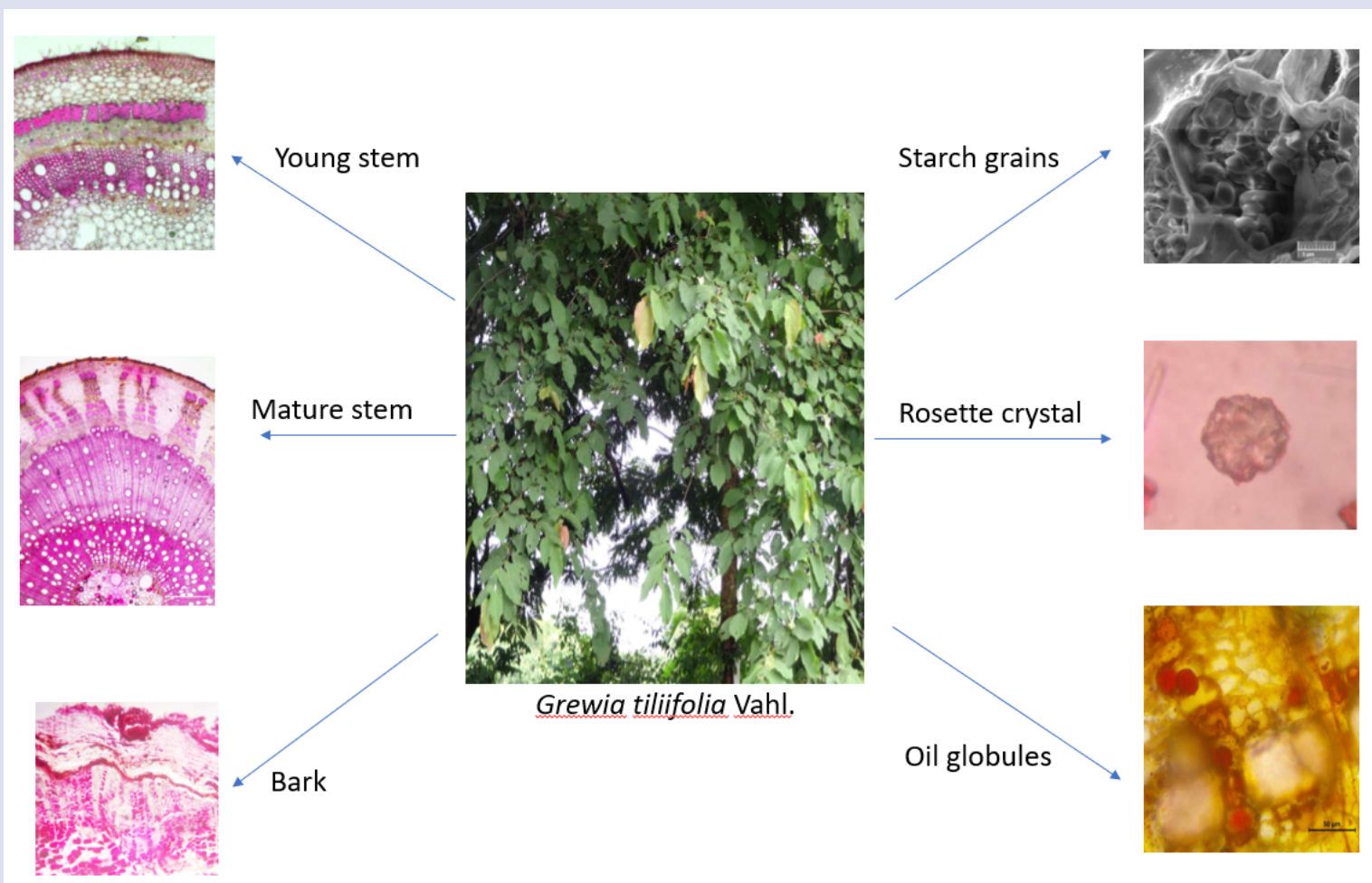

\section{SUMMARY}

- Anatomical studies revealed the presence of prismatic crystals of calcium oxalate, druses, starch grains and mucilage cavities.

- Histochemical studies helped in identifying the tissues of phloem parenchyma as the main localising region of various phytoconstituents.

- Powder microscopic studies can be utilized to confirm the purity of crude drug.

- The physicochemical examinations helped in setting the pharmacopoeial standards.

- The estimation of alkaloids, flavonoids, phenols, tannins, saponins and carotenoids were carried out.

\section{ABOUT AUTHORS}
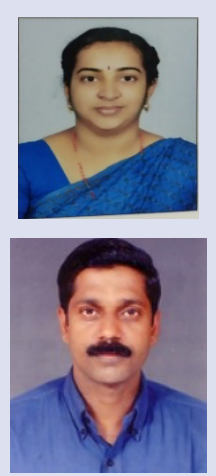

\section{Jaya Kuruvilla}

She is an Assistant Professor in Botany at St. Xavier's College for Women, Aluva, Kerala.

Cite this article: Kuruvilla J, Anilkumar M. Pharmacognostic and Phytochemical Evaluation of the bark of Grewia tiliifolia Vahl Pharmacogn J. 2020;12(5):967-76. 